\title{
Isotopic fractionation associated to nitrate attenuation by ferrous iron containing minerals
}

\author{
Rosanna Margalef-Marti ${ }^{1}$, Raul Carrey ${ }^{1}$, Albert Soler $^{1}$, and Neus Otero ${ }^{1,2, *}$ \\ ${ }^{1}$ Grup MAIMA, SGR Mineralogia Aplicada, Geoquímica i Geomicrobiologia, Departament de \\ Mineralogia, Petrologia i Geologia Aplicada, Facultat de Ciències de la Terra, Universitat de \\ Barcelona (UB), Martí i Franquès s/n, 08020 - Barcelona (Spain). \\ ${ }^{2}$ Serra Húnter Fellowship, Generalitat de Catalunya, Spain.
}

\begin{abstract}
Biotic and abiotic laboratory experiments of nitrate and nitrite reduction by Fe-containing minerals were performed and the isotopic fractionation of the different reactions was calculated in order to determine whether it is possible to distinguish biotic and abiotic reactions involving $\mathrm{N}$ compounds. Results of biotic experiments showed nitrate reduction up to $96 \%$ with transient $\mathrm{NO}_{2}{ }^{-}$accumulation and no significant $\mathrm{N}_{2} \mathrm{O}$ production. No significant nitrate attenuation was observed in abiotic nitrate reduction experiments. Abiotic experiments of nitrite reduction showed a rapid decrease in nitrite concentrations in those experiments with added $\mathrm{Fe}^{2+}$ coupled with a significant $\mathrm{N}_{2} \mathrm{O}$ production. Preliminary results of the $\mathrm{N}$ and $\mathrm{O}$ isotopic fractionation of the biotic experiments of nitrate reduction show differences in the $\varepsilon^{15} \mathrm{~N}_{\mathrm{NO} 3}$ and $\varepsilon^{18} \mathrm{O}_{\mathrm{NO}}$ when different minerals were added. The abiotic experiments of nitrite reduction contrarily, showed similar $\varepsilon^{15} \mathrm{~N}_{\mathrm{NO} 2}$ in all the experiments.
\end{abstract}

\section{Introduction}

During the last years, numerous studies have pointed to the coexistence of biotic and abiotic reactions involving the $\mathrm{N}$ and $\mathrm{Fe}$ biogeochemical cycles in natural environments $[1$, 2]. Among the abiotic reactions, the $\mathrm{NO}_{2}^{-}$reduction by $\mathrm{Fe}^{2+}$ oxidation has been well documented [3,4]. On the other hand, $\mathrm{Fe}^{2+}$ minerals have been suggested to enhance biotic denitrification through the $\mathrm{NO}_{3}{ }^{-}$dependent $\mathrm{Fe}^{2+}$ oxidation (NDFO) process, which is still not well constrained [5]. As the enzymatic $\mathrm{Fe}^{2+}$ oxidation by NDFO microorganisms has not yet been proven, it is unknown whether the $\mathrm{Fe}^{2+}$ oxidation is caused by an enzymatic activity, due to an abiotic reaction mediated by $\mathrm{N}$ intermediates from denitrification or a combination of both $[1,5,6]$.

To trace $\mathrm{N}$ transformation processes, chemical and isotopic characterization have proved to be powerful tools. The enzymatic $\mathrm{NO}_{3}{ }^{-}$reduction provokes an enrichment in the heavy isotopes ${ }^{15} \mathrm{~N}$ and ${ }^{18} \mathrm{O}$ of the unreacted substrate [7], unlike processes such as dilution that could lead to a concentration decrease without influencing the isotopic signature. The same pattern is expected throughout the reduction of all $\mathrm{N}$ intermediate products (e.g. $\mathrm{NO}_{2}{ }^{-}$

* Corresponding author: notero@ub.edu 
or $\mathrm{N}_{2} \mathrm{O}$ ), which will be initially depleted in ${ }^{15} \mathrm{~N}$ and ${ }^{18} \mathrm{O}$ with respect to the substrate. Information on the dual isotope systematics of $\mathrm{NO}_{2}{ }^{-}$and $\mathrm{N}_{2} \mathrm{O}$ throughout the abiotic reduction by $\mathrm{Fe}^{2+}$ is still scarce $[4,8,9]$. Therefore, it is unknown in which extent the isotopic characterization of $\mathrm{NO}_{3}{ }^{-}, \mathrm{NO}_{2}{ }^{-}$and $\mathrm{N}_{2} \mathrm{O}$ might help in distinguishing biotic and abiotic reactions involving the $\mathrm{N}$ compounds.

The aim of this work was to determine at laboratory-scale the $\mathrm{N}$ and $\mathrm{O}$ isotopic fractionation $\left(\varepsilon^{15} \mathrm{~N}\right.$ and $\varepsilon^{18} \mathrm{O}$, respectively) during biotic and abiotic $\mathrm{NO}_{3}{ }^{-}$and/or $\mathrm{NO}_{2}{ }^{-}$ reduction by $\mathrm{Fe}^{2+}$ containing minerals. The selected $\mathrm{Fe}^{2+}$-containing minerals were magnetite (Mag), siderite ( $\mathrm{Sd}$ ) and olivine (Ol), and Mag was also tested nano-sized (MagNP) to quantify changes in reactivity. Special attention was directed on the generation of by-products $\left(\mathrm{NO}_{2}^{-}\right.$and $\left.\mathrm{N}_{2} \mathrm{O}\right)$ throughout the biotic process. Furthermore, the possible abiotic reactivity between the $\mathrm{Fe}^{2+}$-containing minerals and $\mathrm{NO}_{3}{ }^{-}$or $\mathrm{NO}_{2}{ }^{-}$and the possible $\mathrm{N}_{2} \mathrm{O}$ generation through both the biotic and abiotic pathways were evaluated.

\section{Methods}

To accomplish the goal, five series of experiments were performed (Table 1). All series included replicates, a control without mineral and a blank (groundwater or synthetic water alone). The microcosms were set inside a glove box, using $20 \mathrm{~mL}$ serum bottles, crimp sealed with butyl rubber stoppers under an Ar headspace. Incubations were performed at 23 ${ }^{\circ} \mathrm{C}$ and constant shaking in the darkness. The microcosms were sacrificed by turns at time intervals depending on denitrification dynamics. Control and blank microcosms were sacrificed at the end of the experiment.

Table 1. Experimental conditions of the batch experiments. R stands for the number or replicates.

\begin{tabular}{|c|c|c|c|}
\hline Experiment & Conditions & $\mathbf{R}$ & Code \\
\hline \multirow{2}{*}{$\begin{array}{l}\text { Biotic denitrif. }\left(\mathrm{NO}_{3}{ }^{-}\right) \\
\text {with groundwater }\end{array}$} & Groundwater $\left(\mathrm{NO}_{3}^{-}\right)+$sediment & 3 & BioSedGW-C \\
\hline & Groundwater $\left(\mathrm{NO}_{3}^{-}\right)+$mineral + sediment & $10(*)$ & BioSedGW-Min \\
\hline \multirow{2}{*}{$\begin{array}{l}\text { Biotic denitrif. }\left(\mathrm{NO}_{3}{ }^{-}\right) \\
\text {with synthetic water }\end{array}$} & Synthetic water $\left(\mathrm{NO}_{3}{ }^{-}\right)+$sediment & 3 & BioSedSW-C \\
\hline & Synthetic water $\left(\mathrm{NO}_{3}{ }^{-}\right)+$mineral + sediment & $3(*)$ & BioSedSW-Min \\
\hline \multirow{2}{*}{$\begin{array}{l}\text { Abiotic denitrification } \\
\left(\mathrm{NO}_{3}^{-}\right) \text {with } \mathrm{Fe}\end{array}$} & Synthetic water $\left(\mathrm{NO}_{3}^{-}\right) \mathrm{FeCl}_{2}$ & 3 & $\mathrm{AbFeNO}_{3}-\mathrm{C}$ \\
\hline & Synthetic water $\left(\mathrm{NO}_{3}^{-}\right)+$mineral $+\mathrm{FeCl}_{2}$ & $3(*)$ & $\mathrm{AbFeNO}_{3}-\mathrm{Min}$ \\
\hline \multirow{2}{*}{$\begin{array}{l}\text { Abiotic denitrification } \\
\left(\mathrm{NO}_{2}^{-}\right) \text {with } \mathrm{Fe}\end{array}$} & Synthetic water $\left(\mathrm{NO}_{2}^{-}\right)+\mathrm{FeCl}_{2}$ & 10 & $\mathrm{AbFeNO}_{2}-\mathrm{C}$ \\
\hline & Synthetic water $\left(\mathrm{NO}_{2}^{-}\right)+$mineral $+\mathrm{FeCl}_{2}$ & $10(*)$ & $\mathrm{AbFeNO}_{2}-\mathrm{Min}$ \\
\hline $\begin{array}{l}\text { Abiotic denitrification } \\
\left(\mathrm{NO}_{2}^{-}\right)\end{array}$ & Synthetic water $\left(\mathrm{NO}_{2}^{-}\right)+$mineral & $3(*)$ & $\mathrm{AbNO}_{2}$-Min \\
\hline
\end{tabular}

(*) The number of replicates is for each mineral used (Mag, Ol, Sd, Mag-NP)

All samples were filtered through $0.2 \mu \mathrm{m}$ Millipore ${ }^{\circledR}$ immediately when obtained and stored at $4{ }^{\circ} \mathrm{C}$ until analysis. Chemical parameters were determined by standard analytical techniques. The $\delta^{15} \mathrm{~N}-\mathrm{NO}_{3}^{-}, \quad \delta^{18} \mathrm{O}-\mathrm{NO}_{3}^{-}, \quad \delta^{15} \mathrm{~N}_{-} \mathrm{NO}_{2}^{-}$and $\delta^{18} \mathrm{O}-\mathrm{NO}_{2}^{-}$were determined following the cadmium and azide reduction method [10,11]. $\mathrm{N}_{2} \mathrm{O}$ was analyzed using a Pre-Con (Thermo Scientific) coupled to a Finnigan MAT 253 Isotope Ratio Mass Spectrometer (IRMS, Thermo Scientific). Notation is expressed in terms of $\delta$ \%o relative to the international standards AIR (Atmospheric $\mathrm{N}_{2}$ ) for $\delta^{15} \mathrm{~N}$ and V-SMOW (Vienna Standard Mean Oceanic Water) for $\delta^{18} \mathrm{O}$. 


\section{Results and discussion}

Biotic experiments (BioSedGw and BioSedSw) showed a decrease in $\mathrm{NO}_{3}{ }^{-}$concentration during the first week of incubation (Figure 1), up to $42 \%$ in the groundwater batch experiments and up to $64 \%$, in the synthetic water batch experiments. Attenuation was also observed in the control microcosm containing groundwater plus sediment with no mineral addition (BioSedGw-C up to $45 \%$ ). Transient $\mathrm{NO}_{2}{ }^{-}$accumulation (not shown) was much higher in the microcosms containing synthetic water (up $50 \%$ of the initial $\mathrm{NO}_{3}{ }^{-}$) compared to groundwater (up to $10 \%$ of the initial $\mathrm{NO}_{3}{ }^{-}$). After the first week, no significant differences were observed in the microcosms except for the batch containing nano-sized Mag, where about $96 \%$ of $\mathrm{NO}_{3}^{-}$reduction was achieved in 91 days (Figure 1). No significant $\mathrm{NH}_{4}{ }^{+}$concentration was detected, discarding the occurrence of Dissimilatory Nitrate Reduction to Ammonium (DNRA). Headspace $\mathrm{N}_{2} \mathrm{O}$ was below $1 \%$ of the total reduced $\mathrm{N}$, suggesting that the final gaseous product was $\mathrm{N}_{2}$.

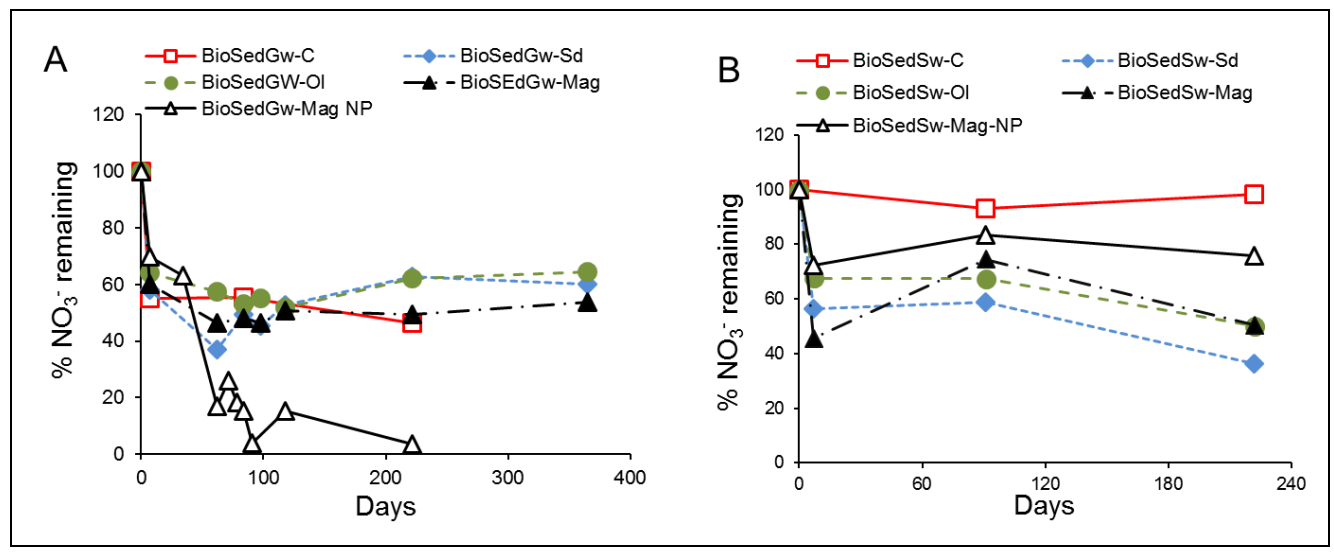

Fig. 1. Percentage of nitrate remaining in the biotic experiments. Experiments with sediment + groundwater + minerals $(\mathrm{A})$ and experiments with sediment + synthetic water + minerals $(\mathrm{B})$.

Abiotic experiments of $\mathrm{NO}_{3}{ }^{-}$reduction (AbFeNO3) showed no significant decrease in $\mathrm{NO}_{3}{ }^{-}$concentration after 220 days (results not shown). With regards to abiotic experiments of $\mathrm{NO}_{2}^{-}$reduction also no significant reduction was observed in microcosms containing synthetic groundwater and micro-sized minerals (AbNO2). However, a rapid $\mathrm{NO}_{2}{ }^{-}$ reduction was observed in the experiments in which microcosms contained synthetic groundwater with $\mathrm{NO}_{2}{ }^{-}$and micro-sized minerals plus dissolved $\mathrm{Fe}^{2+}(\mathrm{AbFeNO} 2$, Figure 2). The beginning of the reaction seemed to be immediate, $\mathrm{NO}_{2}^{-}$complete removal was achieved in microcosms containing mineral plus dissolved $\mathrm{Fe}^{2+}$ or dissolved $\mathrm{Fe}^{2+}$ alone. An increased reduction rate $(\sim 50$ hours) was observed in the microcosms containing micro-Sd compared to the others ( 175 hours). A possible explanation could be an increased dissolution rate of $\mathrm{Sd}$ that increased dissolved $\mathrm{Fe}^{2+}$ availability. $\mathrm{N}_{2} \mathrm{O}$ accumulated at the headspace of the $\mathrm{AbFeNO} 2$ microcosms, mass balance results suggested that $\mathrm{N}_{2} \mathrm{O}$ was the end product, other authors [8] previously observed a large $\mathrm{N}_{2} \mathrm{O}$ accumulation during $\mathrm{NO}_{2}{ }^{-}$ abiotic reduction by $\mathrm{Fe}^{2+}$ oxidation. 

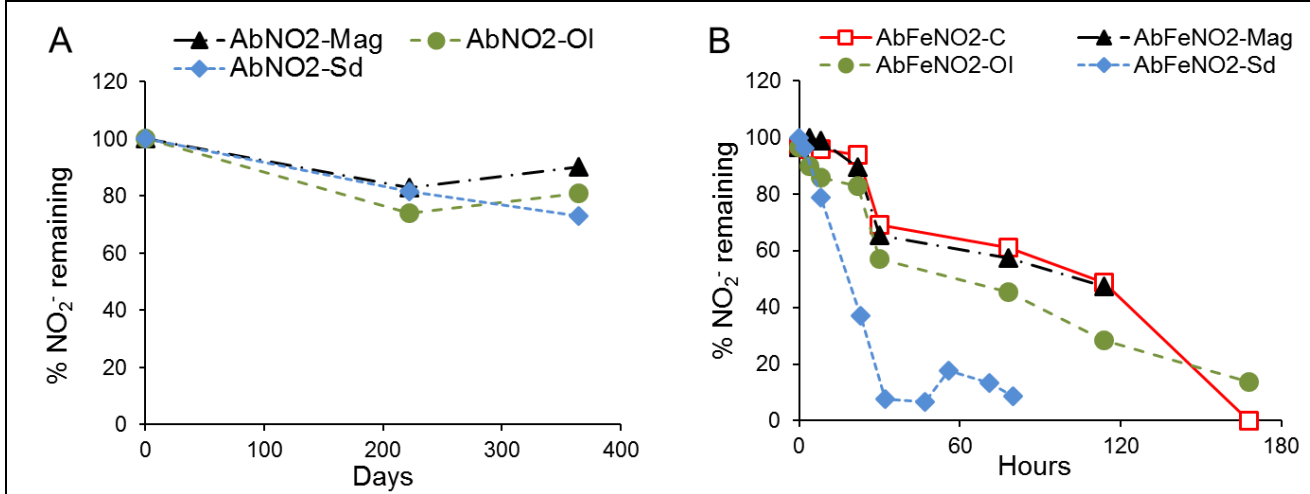

Fig. 2. Percentage of nitrite remaining in the abiotic experiments. Experiments with synthetic water + minerals (A) and experiments with synthetic water + minerals $+\mathrm{Fe}^{2+}(\mathrm{B})$, note the different timescale in the $\mathrm{x}$-axis.

Preliminary results of the isotopic characterization of some of the batch experiments were obtained. Biotic experiments (BioSedGw) showed different isotopic fractionation depending on the added minerals. The higher $\varepsilon^{15} \mathrm{~N}_{\mathrm{NO}}(-28.5 \%$ ) was obtained in the control experiments with no added minerals, decreasing $\varepsilon^{15} \mathrm{~N}_{\mathrm{NO} 3}$ was observed for Mag-NP, Mag, $\mathrm{Sd}$ and $\mathrm{Ol}$ experiments $(-25.4 \%,-15.4 \%,-11.2 \%$ and $-8.7 \%$ respectively) (Figure 3 ). Similarly, the $\varepsilon^{18} \mathrm{O}_{\mathrm{NO}}$ obtained for the control experiment was $-20.7 \%$, and also decreasing values were observed for Mag-NP, Sd, Mag, and Ol experiments (-17.9\%o, $10.3 \%,-8.2 \%$ and $-2.6 \%$ respectively, results not shown). The $\varepsilon^{18} \mathrm{O}_{\mathrm{NO} 3} / \varepsilon^{15} \mathrm{~N}_{\mathrm{NO} 3}$ ratio calculated is $0.3(\mathrm{Ol}), 0.5(\mathrm{Mag}), 0.7$ (Mag-NP), 0.7 (Control) and $0.9(\mathrm{Sd})$. This ratio is similar (except for Sd) to what is observed in most groundwater studies (0.5) but differs from the ratio observed in laboratory experiments with cultures of denitrifying bacteria (close to 1).

Abiotic experiments of nitrite reduction (AbFeNO2) showed a similar isotopic fractionation in all the batch experiments, with an $\varepsilon^{15} \mathrm{~N}_{\mathrm{NO} 2}$ between $-14.1 \%$ and $-17.8 \%$, and no oxygen fractionation (data not shown).

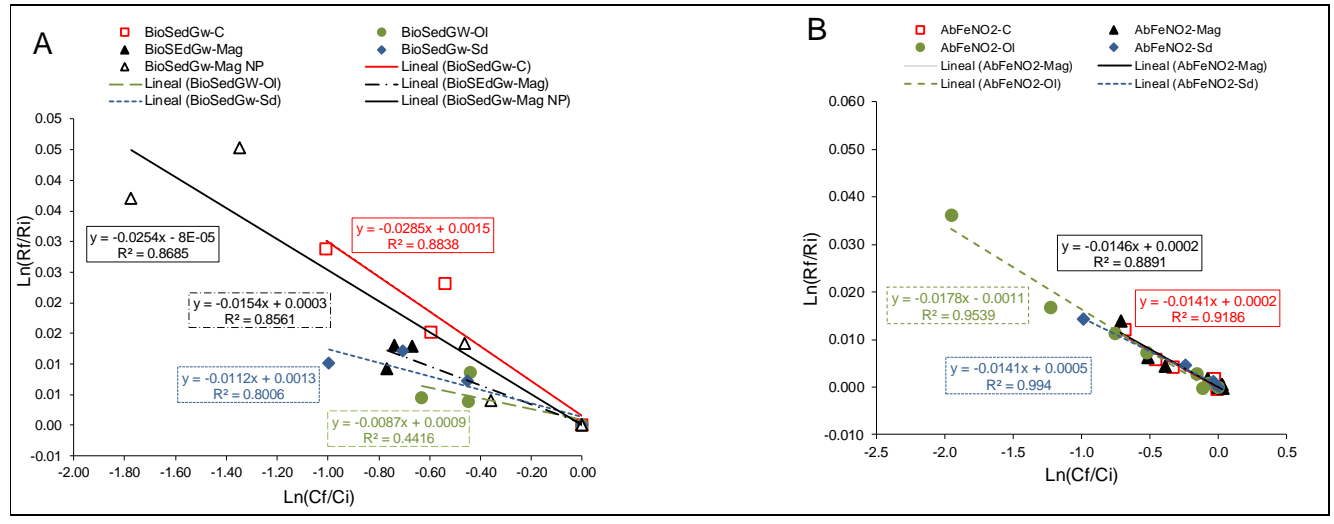

Fig. 3. Isotopic fractionation $\varepsilon^{15} \mathrm{~N}_{\mathrm{NO} 3}$ in the biotic experiments of nitrate reduction with groundwater + sediment + minerals (A). Isotopic fractionation $\varepsilon^{15} \mathrm{~N}_{\mathrm{NO} 2}$ in the abiotic experiments on nitrite reduction with synthetic water + minerals $+\mathrm{Fe}^{2+}(\mathrm{B})$. 


\section{Conclusions}

Results of the biotic experiments showed similar percentages of nitrate reduction regardless the addition of different $\mathrm{Fe}^{2+}$ containing minerals. The highest reactivity was observed in the experiments using magnetite nanoparticles since those experiments reached almost complete $\mathrm{NO}_{3}{ }^{-}$reduction. Transient $\mathrm{NO}_{2}{ }^{-}$accumulation and no significant $\mathrm{N}_{2} \mathrm{O}$ production were observed in all the biotic experiments. No significant nitrate attenuation was observed in abiotic nitrate reduction experiments after 220 days. Abiotic experiments of nitrite reduction showed a rapid decrease in nitrite concentrations in those experiments with added $\mathrm{Fe}^{2+}$, and the final product of $\mathrm{NO}_{2}^{-}$reduction was gaseous $\mathrm{N}_{2} \mathrm{O}$. Preliminary results of the $\mathrm{N}$ and $\mathrm{O}$ isotopic fractionation of the biotic experiments of nitrate reduction show differences in the $\varepsilon^{15} \mathrm{~N}_{\mathrm{NO} 3}$ and $\varepsilon^{18} \mathrm{O}_{\mathrm{NO} 3}$ when different minerals were added. The abiotic experiments of nitrite reduction contrarily, showed similar $\varepsilon^{15} \mathrm{~N}_{\mathrm{NO} 2}$ in all the experiments. The $\varepsilon^{18} \mathrm{O}_{\mathrm{NO} 3} / \varepsilon^{15} \mathrm{~N}_{\mathrm{NO} 3}$ ratio in the biotic experiments showed values around 0.7 similar to values commonly found in groundwater.

This work has been financed by the following projects: REMEDIATION (CGL2014-57215-C4) and PACE-ISOTEC (CGL2017-87216-C4-1-R), financed by the Spanish Government and AEI/FEDER from the UE, and MAG (2017-SGR-1733) from the Catalan Government. Margalef-Marti, R. is grateful to the Spanish Government for the PhD grant BES-2015-072882. We would like to thank the CCiT-UB for providing analytical support, and two anonymous reviewers for their constructive comments.

\section{References}

1. N. Klueglein, A. Kappler. Geobiology 11(2): 180-90 (2013)

2. E.D. Melton, E.D. Swanner, S. Behrens, C. Schmidt, A. Kappler. Nature reviews. Microbiology 12(12): 797-809 (2014)

3. P. Dhakal, C.J. Matocha, F.E. Huggins, M.M. Vandiviere. Env. Sci. \& Technol. 47(12): 6206-13 (2013)

4. K.C. Grabb, C. Buchwald, C.M. Hansel, S.D. Wankel. Geochim. et Cosmochim. Acta 196: $388-402(2017)$

5. A. Price, V.K. Pearson, S.P. Schwenzer, J. Miot, K. Olsson-Francis. Frontiers in Microbiology 9(MAR): 1-15 (2018)

6. H.K.Carlson, I.C. Clark, S. J. Blazewicz, A.T. Lavarone, J.D. Coates. Journal of Bacteriology 195(14): 3260-68 (2013)

7. J. Böttcher, O. Strebel, S. Voerkelius, H.L. Schmidt. J. of Hydrology 114(3-4): 413-24 (1990)

8. C. Buchwald, , K. Grabb, C. M. Hansel, S. D. Wankel. Geochim. et Cosmochim. Acta 186: $1-12(2016)$

9. L. Camille-Jones, B. Peters, J.S., Lezama-Pacheco, K.L. Casciotti, S. Fendorf. Env. Sci. \& Technol. 49(6): 3444-52 (2015)

10. M. R. McIlvin, M. A. Altabet. Analytical Chemistry 77(3163): 5589-95 (2005)

11. E. Ryabenko, M.A. Altabet, D.W.R. Wallace. Limnology and Oceanography: Methods, 7: 545-52 (2009) 